\title{
OS VALORES E AMEAÇAS À GEODIVERSIDADE: UM OLHAR SOBRE JOÃO PESSOA- PB E LITORAL SUL DO ESTADO
}

\author{
THE VALUES AND THREATS TO GEODIVERSITY: A LOOK ON JOÃO \\ PESSOA- PB AND SOUTH COAST OF THE STATE
}

\author{
LOS VALORES Y AMENAZAS PRA LA GEODIVERSIDAD: UMA \\ MIRADA SOBRE JOÃO PESSOA- PB Y COSTERA SUR DEL EATADO
}

\section{Luciano Schaefer Pereira}

Doutorando pelo Departamento de Geografia, Faculdade de Letras, Universidade de Coimbra. Instituto Federal de Educação, Ciência e Tecnologia da Paraíba, Centro de Ciências Humanas e suas Tecnologias (CCHT). Av. $1^{\circ}$ de maio, 720. Jaguaribe. 58015-430 - Joao Pessoa, PB - Brasil

E.mail:1schaefer2@gmail.com

\section{Thiago da Silva Farias}

Graduado pelo Instituto Federal de Educação, Ciência e Tecnologia da Paraíba (2014). Graduando em Geografia na Universidade Federal da Paraíba, no campus João Pessoa. Instituto Federal de Educação, Ciência e Tecnologia da Paraíba, Centro de Ciências Humanas e suas Tecnologias (CCHT). Av. $1^{\circ}$ de maio, 720. Jaguaribe. 58015-430 - Joao Pessoa, PB - Brasil

E.mail:thfarias@hotmail.com

\section{RESUMO}

A geodiversidade refere-se a diversidade de materiais abióticos, no estado sólido ou líquido, que se localizam na interface litosférica. Este substrato e seus recursos hídricos exercem importância como sustentáculo da vida, pela funcionalidade exercida para os seres vivos e pelo fornecimento dos georecursos utilizados pelo homem. Foram identificados oito valores para a geodiversidade da área, nomeadamente os valores intrínseco, ecológico, antropocêntrico, cultural, estético, funcional, científico e educacional. Justificado pela pressão antrópica e pela dinâmica costeira, a geodiversidade sofre uma série de ameaças, tendo sido identificados onze ameaças potenciais. São elas: a extração de georecursos, a expansão urbana, a restauração de aterros, a mudança no traçado de rios, o desmatamento, a agricultura, o turismo, a remoção de espécies geológicas para fins não-científicos, a mudança no nível do mar, as atividades militares e a iliterácia cultural. O reconhecimento destes valores e ameaças faz-se necessário para que as estratégias de geoconservação logrem êxito.

Palavras-chave: Geodiversidade; Valores e Ameaças; João Pessoa; Litoral Sul; Geoconservação 


\begin{abstract}
Geodiversity is the result of a slow evolution from the early Earth, it refers to diversity of abiotic materials, in solid or liquid form, which are located in the lithospheric interface. This substrate and its water resources exert importance for life on the planet, as the basis of life, functionality exercised for living beings and for providing the georesources used by man. Eight values for geodiversity of the area were identified, namely intrinsic, ecologic, anthropocentric, cultural, aesthetic, functional, scientific and educational values. Justified by human pressure and the coastal dynamics, geodiversity undergoes a series of threats, have been identified eleven potential threats. They are: extraction of georesources, urban expansion, ladfill restoration, river management, deforestation, agriculture, tourism, removal of geological specimens, sea-level change, military activity and lack of information. The recognition of these threats it is necessary for the geoconservation strategies are to succeed.
\end{abstract}

Keywords: Geodiversity; Values and Threats; João Pessoa; South Coast; Geoconservation

\title{
RESUMEN
}

La geodiversidad se refiere a la diversidad de materiales abióticos, en estado sólido o líquido, que se encuentran en la interfaz de la litosfera.Este sustrato y sus recursos hídricos ejercen importancia como sustento de la vida, por la funcionalidad ejercida para los seres vivos y para proporcionar los georecursos utilizados por el hombre. Fueron identificados ocho valores para la geodiversidad de el área, incluyendo los valores intrínseco, ecológico, antropocéntrico, cultural, estético, funcional, científico y educacional. Justificado por la presión humana y por la dinámica costera, la geodiversidad sufre una serie de amenazas, siendo identificadas once amenazas potenciales.Son estas: la extracción de los georecursos, la expansión urbana, la restauración de canteras, la mudanza en el trazado de los ríos, el deforestación, la agricultura, el turismo, la remoción de las especies geológicas para fines no científicos, la mudanza en el nivel del mar, las actividades militares y el analfabetismo científico. El reconocimiento de estos valores y amenazas son necesarias para que las estratégias de geoconservación logren el éxito.

Palabras claves: Geodiversidad; Valores y Amenazas; João Pessoa; Costa Sur; Geoconservación.

\section{INTRODUÇÃO}

A geodiversidade representa a herança da história evolutiva da Terra e o substrato para a fixação da vida, sendo o componente abiótico tão importante quanto o biótico. Esta série de valores, motivam, assim propostas de geoconservação. O termo 'Geodiversidade' surgiu na literatura geocientífica em resposta à disseminada conceituação de 'Biodiversidade', cujo papel dos biólogos, em especial, foi fundamental para sua proliferação e consolidação (Nieto, 2001, p 3). Entretanto, o conceito de Biodiversidade está consolidado nos meios 
científicos, principalmente após a Conferência do Rio (1992), e o aporte de materiais elaborados sobre o tema é desigual quando comparado à Geodiversidade, até mesmo porque sua conceitualização e sistematização é anterior.

O professor doutor Marcos A. do Nascimento, da Universidade Federal do Rio Grande do Norte, um dos mais entusiastas pesquisadores do tema, em suas palestras e aulas, faz a seguinte reflexão: ao se digitar a palavra 'Biodiversidade' no buscador Google, em novembro de 2015, por exemplo, o resultado é de aproximadamente 6.210.000 itens; para o termo 'Geodiversidade', o resultado é 71.100, ou seja, uma relação de cerca de 1: 87. Se fizermos a busca em inglês, a relação piora- 1: 223, aproximadamente, para se ter uma ideia de tamanha desigualdade em publicação de artigos, projetos ou disseminação dos temas nas redes sociais, o que repercute em uma carência de bases teórico-metodológicas que permitem avaliar de maneira sistemática a geodiversidade. Esta carência só veio a ser suprida, de maneira lenta, em meados dos anos 2000, quando esta temática vai começar a ser reconhecida para além dos meios acadêmicos, principalmente graças a atuação de geólogos europeus. Mas sua importância científica, econômica, ambiental e, principalmente, política ainda é inferior quando comparada à temática 'biodiversidade', pois a sociedade civil ainda não foi impactada de maneira efetiva sobre a importância da conservação dos elementos abióticos da natureza, a mesma maneira como reconhecem o meio biótico e seu potencial patrimonial.

O papel deste artigo, portanto, é apresentar os valores pertencentes aos diversos elementos da geodiversidade, a citar, as rochas (e seus componentes- minerais, minérios, fósseis, texturas e estruturas), o solo, os recursos hídricos e as geoformas (depósitos e formas), assim como as principais ameaças que estes elementos estão sofrendo, utilizando como exemplo o município de João Pessoa e o litoral sul do Estado da Paraíba, cuja densidade demográfica é a maior do Estado e o fluxo turístico é intenso, resultando em grande pressão sobre os recursos naturais, em especial seu geopatrimônio. Acrescenta-se o fato da dinâmica costeira intensificar a pressão sobre os recursos naturais.

\section{PERCURSO METODOLÓGICO}

Para chegarmos aos resultados propostos para esta pesquisa a partir de uma problemática levantada, obedecemos a uma série de critérios rigorosos de metodologia científica, visando o entendimento da realidade, seus problemas, especificidades, cujas conclusões propostas atuam, da mesma maneira, como sugestões. Esse estudo abordará aspectos de cunho quantitativo (MINAYO, 2000, p. 22), classificada como uma pesquisa exploratória, cuja natureza de exploração permite classificá-la como um estudo de caso 
(GIL, 1991). Recorreu-se, assim, a uma minuciosa análise bibliográfica e a um exaustivo trabalho de campo, com o intuito de aplicar os conceitos, envolvendo valores e ameaças à geodiversidade, ao município de João Pessoa e litoral sul do Estado da Paraíba. O reconhecimento destes valores e ameaças faz-se necessário para que as estratégias de geoconservação logrem êxito.

\section{GEODIVERSIDADE, UMA REVISÃO EPISTEMOLÓGICA}

A primeira vez que o termo 'Geodiversidade' apareceu na literatura foi nos anos 1940, proposto pelo argentino Frederico Alberto Daus, como sinônimo de 'Diversidade Geográfica, segundo Serrano e Ruiz- Flaño (2007). Para o referido autor, a geodiversidade consiste de um "mosaico de paisagens e diversidades culturais do espaço geográfico e as complexidades territoriais em diferentes escalas (locais, distritos e regiões) relacionados aos habitats humanos" (SERRANO; RUIZ- FLAÑO, 2007, p. 140).

Os primórdios acerca da utilização do termo 'geodiversidade', de cunho naturalista, ainda é incerto. Burek e Potter (2002 apud PANIZZA; PIACENTE, 2009, p. 39) sugerem o ano de 1991, durante um congresso internacional sobre geoconservação. Segundo Gray (2008), este termo teria surgido a partir da Convenção da Biodiversidade, evento paralelo à Conferência do Rio, em 1992. Para Nieto (2001) e Gray (2004), sua provável origem teria sido por ocasião da Conferência de Malvern sobre Conservação Geológica e Paisagística, em 1993.

Nos anos 2000-10, uma gama de pesquisadores lançaram diferentes definições acerca da geodiversidade, tendo a maioria pequenas variações sobre o mesmo tema, com o acréscimo ou exclusão de algumas palavras, mas que ao final seu significado pouco variava.

Em 2004, foi lançado o primeiro livro específico sobre o tema, intitulado "Geodiversityvaluing and conserving abiotic nature", elaborado pelo geógrafo inglês Murray Gray, enfocando, como o próprio título se refere, as definiçõesseu histórico e necessidade de proteção, através do estudo de caso em diversos países do mundo, com uma visão integradora entre a geodiversidade e a biodiversidade. Para Gray (2004), geodiversidade é a variedade natural dos elementos geológicos (rochas, minerais e fósseis), geomorfológicos (geoformas, depósitos e processos) e de solo, incluindo suas relações, correlações, interpretações, sistemas e propriedades.

Para esta pesquisa, considera-se a definição de geodiversidade proposta por Serrano e Ruiz- Flaño (2007, p. 144), sendo que consiste na " variabilidade da natureza abiótica, incluindo elementos litológicos, tectônicos, geomorfológicos, edáficos, hidrológico, topográfico e os processos físicos sobre a superfície da terra e nos mares e oceanos, juntos 
com os sistemas gerados pelos processos naturais, endógenos, exógenos e antrópicos, os quais cobrem a diversidade das partículas, elementos e lugares".

Para Serrano e Ruiz Flaño (2009, p. 51), a geodiversidade não é um complemento da biodiversidade, mas um parte individualizável da diversidade natural, não podendo ser separado desta. $\mathrm{O}$ fato de ser individualizável lhe confere um caráter geográfico, onde a escala tem papel fundamental (local, distrital, regional, continental ou planetária), que forma uma rede hierárquica que vai da partícula a gigantescas paisagens que abrigam elementos naturais e culturais. Além disso, os autores consideram a importância do tempo geológico e histórico nos processos naturais (geológicos, geomorfológicos e hidrológicos) e antrópicos que causam mudanças e variações na dinâmica terrestre e dos elementos. Assim, a amplitude de elementos, sistemas e processos envolvidos se alarga, o que mostra também os elementos pertencentes, de modo análogo, à biodiversidade.

O reconhecimento político, no Brasil, da importância da geodiversidade para a manutenção da biodiversidade, mesmo que indiretamente, veio na forma de um documento, elaborado em 2000, conjuntamente entre o setor público (Ministério do Meio AmbienteMMA, Secretaria de Estado de Ciência, Tecnologia e Meio Ambiente do Pará, Instituto de Desenvolvimento Econômico e Meio Ambiente do Rio Grande do Norte, Sociedade Nordestina de Ecologia, Secretaria do Meio Ambiente do Estado de São Paulo e Fundação Estadual de Proteção Ambiental Henrique Luis Roessler, do Rio Grande do Sul) e o terceiro setor (Fundação BIORIO e Conservation International do Brasil).

O Projeto de Conservação e Utilização Sustentável da Diversidade Biológica Brasileira (PROBIO), no âmbito do Programa Nacional de Biodiversidade (PRONABIO) do MMA, foi subdividido em vários subprojetos, entre eles o Subprojeto de Avaliação e Ações Prioritárias para a Conservação da Biodiversidade das Zonas Costeira e Marinha. Este subprojeto resultou em uma relatório técnico, publicado em 2000, em que elementos da geodiversidade são identificados, mesmo que o relatório faça um apologia à biodiversidade (MINISTÉRIO DO MEIO AMBIENTE, 2000). A presença de petróleo no assoalho oceânico; detalhes da geomorfologia costeira, como praias arenosas e lodosas, restingas e costões arenosos; recursos hídricos, como lagoas costeiras, estuários e seus manguezais são alguns dos exemplos de elementos abióticos referidos no documento.

A divulgação da geodiversidade do território brasileiro ascendeu no início deste milênio, a partir do projeto denominado 'Caminhos Geológicos', desenvolvido pelo Departamento de Recursos Minerais do Rio de Janeiro (DRM/ RJ), desde 2001 (MANSUR; SILVA, 2011) e, posteriormente, através da Serviço Geológico do Paraná (MINEROPAR), em 2003, com o 'Programa Sítios Geológicos e Paleontológicos do Paraná' (PIEKARZ; 
LICCARDO, 2006), e que acabara se espalhando para outros estados brasileiros (Rio Grande do Norte, Bahia, São Paulo, Minas Gerais, etc.; NASCIMENTO et al., 2007; NASCIMENTO et al., 2008, p. 37; 48; MANSUR, 2010, p. 21- 22). Em 2005, o Departamento Nacional de Pesquisa mineral (DNPM) iniciou um projeto denominado 'Série de Estudos sobre a Geodiversidade do Brasil', com a elaboração de cartilhas e coleções de minerais e rochas (NASCIMENTO et al., 2008, p. 37). Várias dissertações de mestrado e teses de doutorado tem trabalhado o tema em suas várias vertentes, a exemplo de Covello (2011), Manosso (2012), Pierri (2015), entre outros.

Em seguida, o Serviço Geológico do Brasil (CPRM, 2006) propôs, quando publicou o "Mapa da Geodiversidade do Brasil, escala 1:2.500.000", a como definição de geodiversidade, a "natureza abiótica (meio físico) constituída por uma variedade de ambientes, fenômenos e processos geológicos que dão origem as paisagens, rochas, minerais, solos, águas, fósseis e outros depósitos superficiais que propiciam o desenvolvimento da vida na Terra, tendo como valores intrínsecos a cultura, estético, o econômico, o científico, o educativo e o turístico" (CPRM, 2006).

Estes trabalhos pioneiros do DNPM e CPRM resultaram em um mapeamento da geodiversidade que abrangeu praticamente todos os Estados brasileiros. No Nordeste, por exemplo, todos os Estados já foram mapeados, sendo que todos, com exceção da Paraíba, Sergipe e Alagoas, possuem um livro com o levantamento completo dos elementos mapeados. A maior parte da área deste trabalho foi incluída no Domínio e Unidade Geológica Ambiental denominada "Sedimentos Cenozóicos pouco a moderadamente consolidados, associados a Tabuleiros (DCT)", cujas principais formas de relevo identificadas foram os tabuleiros (g), os tabuleiros dissecados (h), as chapadas e platôs (f) e os degraus estruturais e os rebordos erosivos (q).

Entretanto, em menor grau, foi identificado um domínio denominado "Sedimentos Cenozóicos Inconsolidados ou Pouco Consolidados, depositados em ambiente aquoso (DC)", associados a ambientes de transição marinho/ terrestre e áreas de mangues (2), onde as planícies flúvio-marinhas são as principais formas de relevo (b). Pontualmente, pequenas áreas foram incluídas no domínio das "Sequências Sedimentares Mesozóicas Clastocarbonáticas Consolidadas em Bacias de Margens Continentais (Rift; DSM)", predominando calcários e sedimentos síltico- argilosos (8) e no domínio dos "Sedimentos Cenozóicos Eólicos (DCE)", formado basicamente por dunas móveis (5) e associado à planície costeira (c).

Até os anos 2000, a temática da geodiversidade não constava, diretamente, na pauta das discussões de projetos visando a preservação do patrimônio. Isto pode ser explicado, em parte, porque as discussões acerca desta temática pouco foram dedicados a aplicabilidade 
destes conceitos no planejamento de análise territorial, a partir de uma reflexão acerca dos valores que estes elementos possuem. Alguns destes valores serão discutidos a seguir, assim como as ameaças que a geodiversidade está sofrendo na área de estudo seja por pressão natural, típica da dinâmica costeira, seja por causas antrópicas.

\section{VALORES DA GEODIVERSIDADE EM JOÃO PESSOA E LITORAL SUL DA PARAÍBA}

Apesar dos inúmeros conceitos propostos para a geodiversidade, os pesquisadores são unânimes na importância desta para a vida, como sustentáculo da biodiversidade, o que lhe confere uma série de valores, motivando-a a propostas de geoconservação. Abaixo, destacamos estes valores, segundo Sharples (1995; 2002) e Gray (2004):

- Valor intrínseco (ou de existência): diz respeito ao valor inerente ao meio abiótico per si, que faz parte dele e que o torna diferente e importante em relação às demais, sem a necessidade de requerer estudos mais aprofundados ou pesquisas que justifique este valor. É um valor extremamente subjetivo, o que o torna difícil de ser quantificado. Daí a necessidade de se pensar na 'representatividade' deste bem como um perfil-tipo, para que ele seja preservado (Sharples, 1995, p. 39; 2002, p. 25).

Em uma era antropocêntrica, onde os recursos naturais são pensados estarem à disposição para usufruto das sociedades modernas ao seu bel- prazer, avaliar a geodiversidade por seu valor intrínseco é uma questão filosófica e/ ou de ética ambiental (Gray, 2004, p. 66), uma vez que apenas o homem possui o discernimento de julgar quais elementos da geodiversidade devem ou não preservar.

- Valor ecológico: diz respeito à importância do bem para a manutenção dos sistemas naturais e processo ecológicos que dela fazem parte. Como sistemas naturais, entende-se os processos geológicos, geomórficos e edáficos interagindo com o meio biótico, assim como a manutenção dos processos biológicos que deles dependem (Sharples, 1995, p. 39). Este valor comprova a importância do meio físico como sustentáculo da vida. Não se pode pensar em conservação das espécies biológicas sem antes esforçar-se em preservar o meio abiótico. $\mathrm{O}$ manejo inadequado do solo, por exemplo, pode resultar em seu desgaste e, a longo prazo, em sua extinção. Assim, este solo não só estaria inviável para a agricultura como para a existência de microrganismos em seu interior. Foi redefinido por Gray (2004) como 'função ecossistêmica' associada ao valor funcional.

$\mathrm{Na}$ área de estudo, destaca-se o Estuário do Rio Paraíba, típico sistema ecológico tropical costeiro, cujos sedimentos lamacentos foram depositados ao longo da foz protegida do rio por barreiras arenosas, com forte influência das marés, 
adentrando no curso inferior do rio, em franco desenvolvimento, formando extensos manguezais. Estes manguezais podem aparecer também ao longo dos 'maceiós', denominação regional para pequenas lagunas que tornaram-se isoladas por cordões arenosos depositados pela ação marinha, bastante comuns no litoral sul da Paraíba. A dinâmica e energia de deposição é baixa, constituindo zonas pantanosas. São formados por sedimentos areno-argilosos ricos em matériaorgânica e conchas, o que lhe fornece uma coloração escura, onde desenvolveu-se um flora típica, adaptada a mistura de águas doces e salgadas, baixa oxigenação, e animais de pequeno porte, especialmente crustáceos e peixes que vão se alimentar e se reproduzir, transformando o ecossistema em um berçário ecológico.

- Valor antropocêntrico (geopatrimonial/ econômico): correspondem aos valores associados às necessidades de exploração pelo ser humano, seja através da mineração, agricultura ou construção civil, proporcionando uma visão patrimonial sobre eles, geralmente associados aos solos, geoformas e rochas. Podemos acrescentar os recursos hídricos, subterrâneos e superficiais, necessários à vida, os quais não sobreviveríamos com sua ausência.

Este valor foi redenominado de 'Valor Econômico' por Gray (2004, p. 85). Neste contexto, o autor insere uma série de bens que são passíveis de serem utilizados como recursos pelo homem, a citar: recursos energéticos (não renováveis, a exemplo do petróleo, urânio e carvão e renováveis, como as fontes geotérmicas e as hidrolétricas, que dependem diretamente da topografia; marés, ondas e ventos; pode-se acrescentar, também, outras fontes não renováveis, como o xisto betuminoso e o gás natural, que também tem na litosfera sua origem); minerais preciosos (geralmente usados na indústria joalheira, como água marinha, esmeralda, berilo, etc.), metálicos (minerais nativos, como o ouro e a prata; minério de ferro, magnésio, etc. ligado a oxigênio, enxofre, carbonatos, entre outros; de origem hidrotermal, como os pegmatitos;), de construção (como a argila para produção de telhas e tijolos, a brita para a construção civil ou pavimentos, blocos de rochas para o piso de prédios, cemitérios, etc., como o mármore ou granito, areia para a produção de vidro ou o calcário para cimento, entre outros), os fósseis (cuja comercialização depende da sua raridade) e industriais (que possuem propriedades físicas e químicas particulares, como o cobalto, diamante, asbestos, entre outros).

Por ser uma área geologicamente associada a uma bacia sedimentar, este substrato, na forma de rochas calcárias, extraídas para fabricação de cimento; argilas, com fabricação de tijolos e telhas em olarias dispersas pela região metropolitana de João 
Pessoa; areia para a indústria da construção civil, são alguns exemplos de como este valor está presente na geodiversidade da área.

Dentre estas necessidades, Sharples (1995, p. 39- 40; 2002, p. 11) acrescenta a importância para fins científicos, educacionais, estéticos, recreacionais (turísticos) e como paisagens culturais, para a instalação de comunidades e a associação que estas fazem com relação aos aspectos religiosos/ espirituais. Entretanto, todos estes aspectos foram desmembrados posteriormente, tornando-se novos valores da geodiversidade, que serão analisados em seguida.

- Valor cultural: diz respeito ao valor que o ambiente físico possui para determinadas sociedades, em razão de seu significado social ou comunitário (Gray, 2004, p. 70). Nestes significados, inclui-se a geomitologia (toponímias associadas a feições geomórficas, geológicas, entre outras, como é o caso do termo 'Paraíba' - 'Para'iwa, de origem indígena tupi-guarani, onde pa'ra, "rio" e iba, "ruim, impraticável”,) ou a lendas e folclores locais, história/ arqueologia (evidências da presença de civilizações antigas na forma de pinturas rupestres, petroglifos, hieróglifos, tumbas; a utilização de artefatos com matéria prima rochosa, como facas, moinhos, etc.; a escolha de determinado sítio devido a uma certa finalidade, como a defesa ou; o uso de rochas como artefatos rituais, etc.), espiritual (associar a determinadas feições geológicas ou geomorfológicas um caráter religioso ou espiritual, relacionando sua gênese a deuses ou espíritos ou transformadas em locais sagrados por determinado evento religioso) e o sentido de lugar (refere-se a importância que determinadas paisagens possuem para a fixação de uma civilização ou o elo que alguns povos atuais traçam com o ambiente físico que os rodeia ou determinadas porções deste ambiente, como a Ponta do Seixas que se tornou um geossímbolo de João Pessoa e Paraíba).

Vários elementos da geodiversidade se destacam, na área deste estudo, pelo valor cultural. Citamos como exemplo, a Pedra do Amor, Fonte Tambiá, Praça do Trabalho, Fazenda da Graça e o calcário da Praia de Tambaba (figura 1), entre outras.

a. Pedra do Amor(figura 1a): no limite das praias de Jacumã e do Amor, uma abertura no calcário da Formação Maria Farinha, gerado pela abrasão marinha e na forma de coração, denota o aspecto folclórico deste valor da geodiversidade. Segundo moradores locais, todo aquele que passa por esta abertura, estando solteiro, em breve encontra sua alma gêmea;

b. Fonte Tambiá: o nome desta fonte está associado a uma lenda local, denotando o aspecto folclórico de seu valor cultural. Segundo Rodriguez (1962, p. 113), uma jovem virgem 
indígena de nome Aipré, da tribo Potiguara, teria se apaixonado por um guerreiro Cariri, portanto inimigo de sua tribo, chamado Tambiá. Após a morte deste pelos seus parentes, a jovem chorou durante 50 luas sobre seu túmulo, em cujo pranto deu origem às águas da fonte. Esta é a lenda mais conhecida e divulgada pelos tempos. Entretanto, existe uma outra em que uma índia tabajara suplica à mãe água para que seu amor, o índio Tambiá, não vá embora. No dia de sua ida, o índio é picado por uma centopeia, logo em seguida esmagando com força o quilópode. A Mãe Terra, assim, é rasgada, e de suas fendas brotam as águas que deu origem à fonte Tambiá (MEDEIROS, 1994, p. 46).

c. Fazenda da Graça: no interior da área da fábrica de extração de calcário da CIMPOR existe um sítio arqueológico, com cerca de 400 ha de área. Esta fazenda possui a Capela da Graça e inúmeros artefatos arqueológicos encontrados em seu subsolo, sendo que a Capela é um monumento tombado pelo IPHAN, desde 30 de abril de 1938, sendo um marco não só arquitetônico, mas também cultural de sua época.

d. Praça do Trabalho(figura 1b): popularmente conhecida como Praça da Pedra, localizada no Centro Histórico, possui um monólito de granodiorito porfirítico no seu interior. Curiosamente, esta praça se refere à única presença de rocha granitóide no litoral paraibano, mesmo que ex situ, litoral este geologicamente associado à bacia sedimentar Paraíba- Pernambuco. Na verdade, este monólito, segundo informações de moradores locais, foi trazido para o local entre os anos 1920 e 1930. Existem duas versões, não oficiais, de como este monólito chegou à referida praça. Na primeira versão, no final dos anos 1920, para comemorar o Dia do Trabalho, a rocha teria sido trazida do município de Cruz do Espírito Santo até o Rio Sanhauá, de trem, e através de charretes, à praça. O problema desta versão é que este tipo de granitóide não aflora no referido município, assentado sobre uma bacia sedimentar. A segunda versão é de que, em 1932, o monólito, localizado no município de Bananeiras (PB), foi trazido para a praça como homenagem ao aniversário de falecimento do então presidente João Pessoa, que num dado momento, em suas andanças para o interior, teria descansado à sombra desta rocha. Bananeiras registra a presença de rochas granodioríticas semelhantes àquela da Praça da Pedra, em afloramentos ao longo da rodovia PB-105, o que corroboraria com esta versão (PEREIRA et al., 2013, p. 300). Esta monólito é um exemplo do aspecto histórico do valor cultural da geodiversidade.

e. Praia de Tambaba(figura 1c): considerada um lugar sagrado para os indígenas Tabajara, servindo como um cemitério onde, num passado remoto, sepultavam seus mortos. Destaca-se as redondezas de um afloramento do calcário Maria Farinha, com um coqueiro na parte superior, localizado no limite estirâncio- antepraia, que possui um 
significado espiritual para esta etnia pois relaciona os ancestrais com os espíritos das águas e das matas (FARIAS; BARCELLOS, 2014).

f. * Valor estético: possui um apelo visual, sendo um conceito intangível da geodiversidade, variando de uma escala de afloramento a paisagens gigantescas (GRAY, 2004, p. 81- 82) e de difícil quantificação. Normalmente, este valor está associado às grandes cordilheiras montanhosas, às praias e suas falésias, ao vales verdes com suas flores, onde vários elementos se misturam gerando um sentimento de prazer e satisfação a quem os vê. É um dos principais valores da geodiversidade adotados, mesmo inconscientemente, pela escolha de destinos turísticos de natureza e pelos geoturistas (GRAY, 2004, p. 83), quenão somente estão em busca de conhecimento científico, como no caso dos últimos, mas também de uma paisagem selvagem com mínima interferência humana e, principalmente, bela. E é esta beleza que une, não somente os geoturistas, mas os turistas convencionais e os amantes das artes, pois inspira-os em uma gama de atividades, a exemplo da Provence francesa para o pintor Van Gogh, ou do Colorado para o diretor John Huston.

Figura 1-Função cultural com vários significados. a) o aspecto geomitológico da Pedra do Amor; b) a importância histórica do monolito da Praça da Pedra e; c) o afloramento de calcário na Praia de Tambaba e seu valor espiritual para a etnia indígena Tabajara.
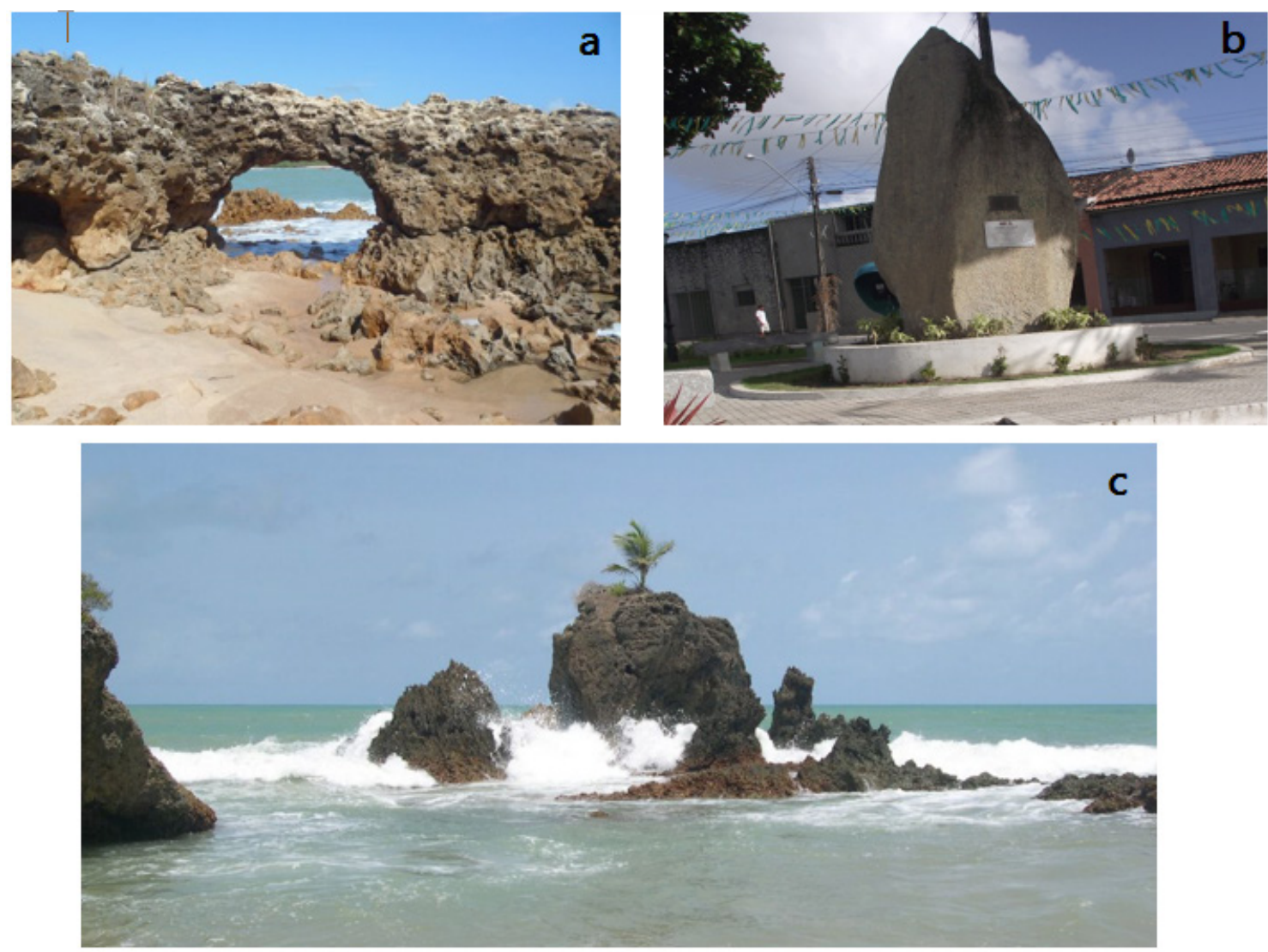

Foto: o autor. 
O pôr-do-sol da praia do Jacaré, as falésias do litoral, as iconografias retratando a nascente cidade, no século XVII são alguns exemplos de como a geodiversidade da área deste trabalho possui o valor estético em todas as suas nuances (figura 2).

Valor funcional: para Gray (2004, p. 114- 125), a geodiversidade funciona como o palco de atuação da vida humana e suas atividades e obras (função utilitária, ou antropogênica, como definiu Shaples, 2002), como peça de um complexo geossistêmico (função geossistêmica) ou como substrato para a sustentação do sistema ecológico (função ecossistêmica, ou ecológica, segundo Sharples, 2002, já definida). Na função utilitária, temos como exemplo a instalação de pistas de ski no pico das montanhas, tendo uma correlação estreita com o valor econômico, proposto pelo mesmo autor. Ademais, serve como um armazenador de elementos químicos, como o carbono ou até mesmo de corpos humanos em decomposição, no caso de catacumbas e cemitérios; a geologia das camadas rochosas afeta o comportamento químico das águas subterrâneas, assim como pode servir como filtro, controlando a poluição das águas subterrâneas e superficiais e; possui elementos químicos essenciais a vida das plantas e de seres microbianos, tendo uma importância ímpar para a agricultura, como a produção de cana, por exemplo que na área, possui relação direta com o solo tipo massapê formado pela decomposição do calcário.

Figura 2 - Valor estético da geodiversidade. a) Geoformas de grande beleza cênica, motivadora da atividade turística na costa da Paraíba; b) pôr-do-sol no estuário do Rio Paraíba, ao som do Bolero de Ravel executado ao vivo por músico local; c) vista de parte do centro histórico de João Pessoa a partir do Rio Sanhauá, afluente do Rio Paraíba, na posição em que foi retratado por pintores setecentistas, conforme figura d).
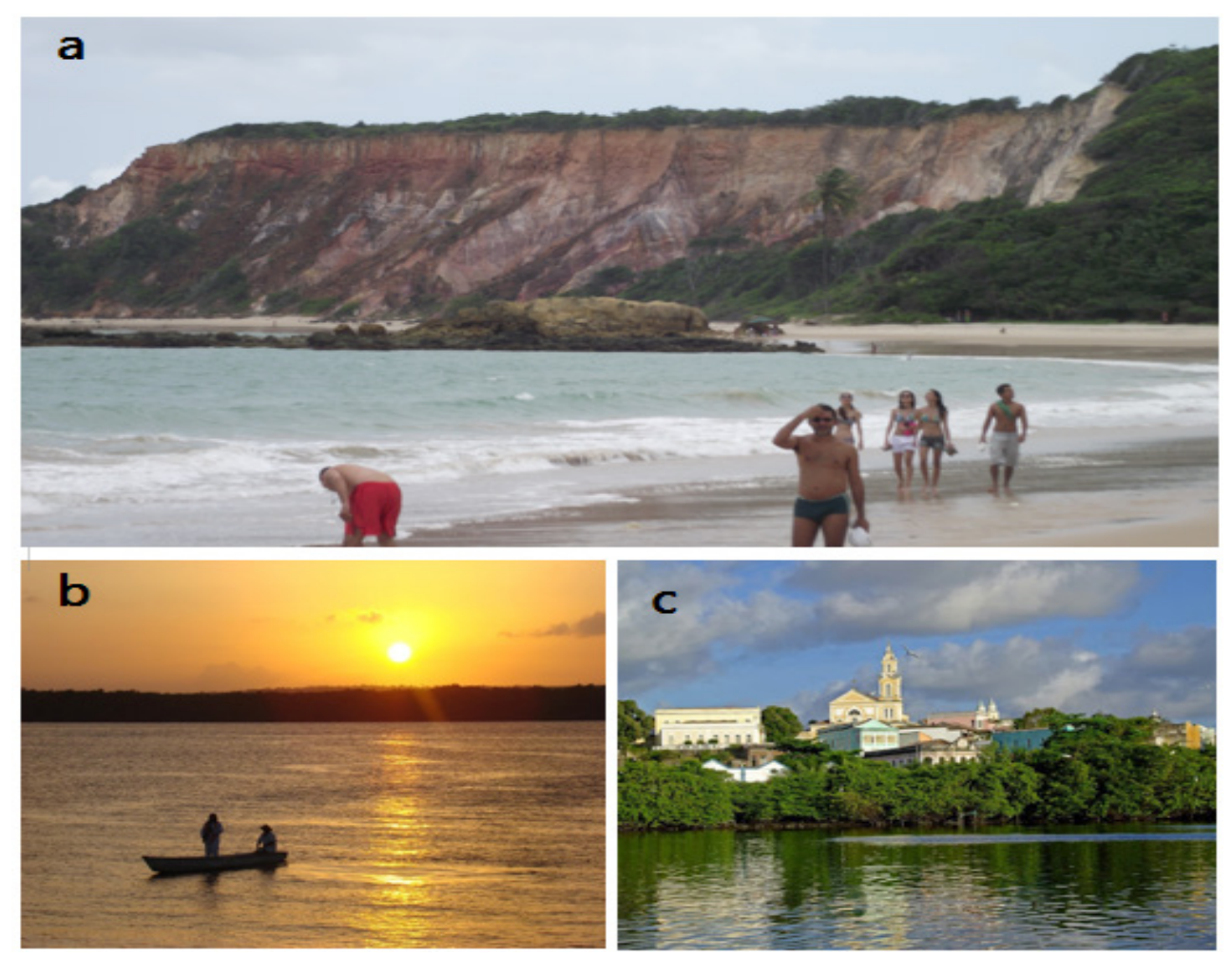


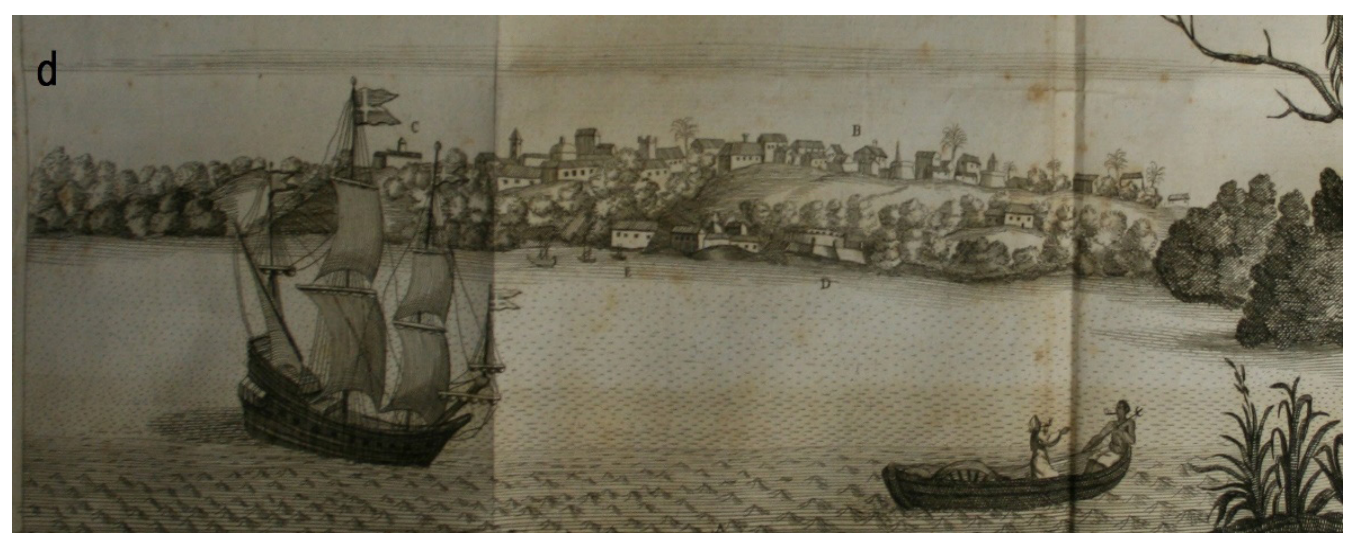

Fonte: a) o autor; b) blog Belezas Naturais; c) Reginaldo Marinho; d) Santa Teresa(1698)

Considerando que os eventos físicos que ocorrem na crosta possui relação direta com os três principais sistemas orgânicos da Terra (climático- atmosfera e hidrosfera; das placas tectônicas- litosfera, astenosfera e manto e; sistema geodinâmico- do núcleo, acrescido da biosfera, que ocupa partes da litosfera, atmosfera e hidrosfera), ou seja, a superfície terrestre (PRESS et al., 2003) está associada a um sistema aberto, com troca de energia e calor, cujos eventos devem ser analisados de forma holística e interdependentes, onde o equilíbrio dinâmico tem papel fundamental na manutenção dos ecossistemas. A este valor funcional específico, Gray (2004) chama de função geossistêmica.

Pesquisadores do Instituto Federal de Educação, Ciência e Tecnologia da Paraíba (IFPB) estão realizando a avaliação dos gases de efeito estufa por meio da quantificação dos fluxos de $\mathrm{CO}_{2}$ do solo da Floresta da Restinga, em Cabedelo, para a atmosfera. O objetivo da pesquisa é contribuir para a valoração ambiental e para a política de pagamento por serviços ecossistêmico, como um referencial para a geração de créditos de Carbono. Este é outro exemplo do valor funcional de um elemento da geodiversidade, no caso o solo da restinga.

- Valor de pesquisa (científico) e educacional: a geodiversidade é um laboratório, onde as aulas teóricas são postas em prática, tendo um poder educativo formal ou não, seja em locais em que os processos dinâmicos são vistos in situ, como no estuário dos rios, na costa, em ambiente montanhoso ou áreas vulcânicas ativas, com suas respectivas geoformas e depósitos, executado por geomorfólogos, ou através de relictos que auxiliam no entendimento da história do planeta, como afloramentos rochosos, com suas feições estruturais, texturais e estratigráficas, fósseis, paragênese mineral, entre outros, objeto de estudo dos geólogos ou perfis de solo, pelos pedologistas. A aplicabilidade deste valor possibilita que danos materiais e humanos sejam evitados, quando se vive em potenciais áreas de risco, como 
encostas, bordas vulcânicas, zonas sujeitas a terremotos, entre outras (BRILHA, 2005, p. 40). Ademais, Gray (2004, p. 128-129) sugere que alguns afloramentos são importantes como resquícios de exemplos utilizados para a formulação de teorias científicas, a exemplo dos afloramentos de beach rocks, no litoral carioca, visitados por Charles Darwin, que o ajudou em sua caminhada pelos meios científicos (MANSUR, 2010, p. 96- 97) ou servem como ferramenta para o monitoramento ambiental presente ou passado. Por exemplo, a datação isotópica do oxigênio preso em bolhas de ar em minerais ou em testemunhos de gelo pode ser utilizado para se conhecer o paleoambiente de formação deste mineral ou do gelo. $\mathrm{Na}$ área deste projeto, sobressaem-se vários elementos da geodiversidade com este valor, a exemplo dos terraços marinhos, para o entendimento da dinâmica costeira, assim como afloramentos rochosos com seus elementos e feições, que auxiliam para se entender evolução da história da bacia.

Na perspectiva de valoração da geodiversidade, a tabela 1 propõe exemplos para seus elementos, concernentes à área desta pesquisa.

\section{AMEAÇAS À GEODIVERSIDADE E EXEMPLOS LOCAIS}

O fortalecimento de uma discussão voltado à medidas de conservação da geodiversidade se deu no momento em que os cientistas da Terra se deram conta que os materiais da crosta são tão sensíveis à ação humana e da natureza quanto à biodiversidade. Gray (2004, p. 133174) enumerou uma série de ameaças, em especial antrópicas, que serão agora discutidas, exemplificadas na região em discussão.

- Extração de georecursos: abrange todos os recursos minerais, metálicos ou não metálicos, extraídos da crosta, através de minas, garimpos a céu aberto ou pedreiras, ou sedimentos, como argila e areia, rochas ornamentais, recursos energéticos, entre outros. Este tipo de exploração resulta em cicatrizes expostas na superfície e entulhos, quando a exploração é desativada ou até mesmo a nível de afloramento.

Um exemplo da exploração dessa natureza foi executado pelo governo da Paraíba em um programa de incentivo ao desenvolvimento do turismo no estado.O Programa de Ação para o Desenvolvimento do Turismo no Nordeste (PRODETUR-NE), criado nos anos 1980, tratava-se de uma política de turismo, se restringindo à criação de infraestrutura urbana para atrair fluxos turísticos em municípios considerados chave para os idealizadores, e João Pessoa, na Paraíba, foi selecionada para tal (CRUZ, 2000, p. 38; MOURA; GARCIA, 2007), para desenvolver o chamado Projeto Cabo Branco, ou Costa do Sol, datado de 1988, com um programa de crédito facilitado para o setor público que dinamizasse a atividade 
turística através da instalação de equipamentos hoteleiros e infraestrutura compatível, e o litoral sul foi escolhido para a implantação deste projeto, em especial uma área com 654 ha entre os Rios Aratu e Cuiá (MOURA, 2008, p. 46- 47; 101), ou seja, a Bacia do Rio Jacarapé, área esta extremamente vulnerável à ação antrópica.

Numa $1^{\text {a }}$ etapa do Projeto, em 1989, o governo municipal, através da Empresa de Turismo da Paraíba- PBTur realizou o EIA que, mesmo sem audiência pública, foi aprovado pelo Ministério Público. Entretanto, os desmandos iniciais dos gestores obrigaram o projeto ter suas ações embargadas pelo IBAMA, em 1991. Entre estes desmandos, citamos degradação de Mata Atlântica, para retirada de barro e areia destinada a aterros; desmonte de falésias, causando erosão; aterramento de mangues na foz do Rio Jacarapé e retirada de vegetação de APPs, todos estas infrações no Auto do IBAMA, datado de 14 de março de 1991 (PEDROSA, 1999, p. 19).

Em 1994, divergências entre o Governo do Estado e a Prefeitura Municipal fizeram com que o projeto fosse abortado restando apenas as obras relacionadas ao esgotamento sanitário eabastecimento de água, e o embargo, citado anteriormente, foi suspenso em 1996, após a elaboração de um Plano de Recuperação de Áreas Degradadas. Logo em seguida, processaram-se as obras para construção da PB-008, que serviria de eixo de ligação entre João Pessoa e o litoral sul. Esta rodovia obstaculizou o fluxo de água do rio Jacarapé, formando um grande barramento, que dificultou a circulação de água a jusante para valores ínfimos, afetando o ciclo hidrológico local. 
Tabela 1. Tipos de valores da geodiversidade da área de estudo, com sua descrição, aspectos e exemplos
Tipo de Valor
Descrição
Aspectos
Exemplos na área de estudo

Intrínseco Meio abiótico livre de avaliação

\begin{tabular}{|c|c|c|c|}
\hline \multirow{4}{*}{ Cultural } & \multirow{4}{*}{$\begin{array}{l}\text { Valor dado pela sociedade a } \\
\text { algum aspecto do ambiente } \\
\text { físico pelo seu significado } \\
\text { social, cultural, religioso ou } \\
\text { comunitário. }\end{array}$} & $\begin{array}{l}\text { Folclórico/ } \\
\text { geomitológico }\end{array}$ & Topônimo 'Parahyba'; Fonte Tambiá; Pedra do Amor; Capela de N. S. da Penha \\
\hline & & $\begin{array}{l}\text { Arqueológico/ } \\
\text { histórico }\end{array}$ & $\begin{array}{l}\text { Fazenda da Graça; edificação do Centro Histórico tendo como georecurso } \\
\text { o calcário; cidade alta e cidade baixa; triângulo defensivo no Estuário do Rio } \\
\text { Paraíba; monólito na Praça do Trabalho. }\end{array}$ \\
\hline & & Espiritual & Praia de Tambaba para os indígenas Tabajara \\
\hline & & Sentido de lugar & Geosímbolo Ponta do Seixas. \\
\hline \multirow{4}{*}{ Estético } & \multirow{4}{*}{$\begin{array}{l}\text { Refere-se ao apelo visual } \\
\text { fornecido pelo ambiente físico. }\end{array}$} & Paisagem local & Estuário do Rio Paraíba; falésias; pôr-do-sol na Praia do Jacaré; praias. \\
\hline & & Geoturismo/ lazer & $\begin{array}{l}\text { Turismo de massa (sol e mar), incluindo mergulho em piscinas naturais, recifes, } \\
\text { passeios de bugies e 'banana boat', mas sem atividades geoturísticas. }\end{array}$ \\
\hline & & Inspiração artística & Pinturas de Franz Post (séc. XVI) \\
\hline & & Apreciação à distância & $\begin{array}{l}\text { Farol do Cabo Branco; praia naturista de Tambaba; ponto mais oriental das } \\
\text { Américas. }\end{array}$ \\
\hline \multirow{5}{*}{ Econômico } & \multirow{5}{*}{$\begin{array}{l}\text { Diz respeito aos recursos } \\
\text { abióticos passíveis de exploração } \\
\text { pela sociedade. }\end{array}$} & Energia & $\begin{array}{l}\text { Projeto Mandala, em alguns minifúndios, com aproveitamento de resíduos } \\
\text { sólidos, de origem animal, como adubo (ex: fosfatos, esterco, ...) }\end{array}$ \\
\hline & & Minerais, no geral & Calcário para fabricação de cimento; argila para fabricação de tijolos e telhas \\
\hline & & Construção & Areia de dunas inativas e praias; brita à partir do calcário \\
\hline & & Fósseis & $\begin{array}{l}\text { Biomicrito com foraminíferos; icnofósseis nos calcários da Formação Maria } \\
\text { Farinha. }\end{array}$ \\
\hline & & Solos & Solo massapê para o desenvolvimento da cultura canavieira \\
\hline
\end{tabular}

Revista da Associação Nacional de Pós-graduação e Pesquisa em Geografia (Anpege).

p.141-166, V.12, n.17, jan-jul.2016. 
Tipo de Valor Descrição

Aspectos

Corresponde ao papel utilitário que os elementos da geodiversidade possuem para a sociedade, assim como fornecedor dos substratos, habitats e processos abióticos para manter sistemas ecológicos e físicos.

Funcional

Os elementos da geodiversidade como um laboratório para propósitos científicos e educacionais

\section{Exemplos na área de estudo}

Expansão imobiliária nos terraços holocênicos; pássaros migratórios na Restinga de Cabedelo; especificações do solo para a agricultura; escolha do sítio onde foi fundada João Pessoa ou edificado os fortes para protege-la; valorização dos imóveis do Altiplano devido à vista privilegiada.

\begin{tabular}{cl}
\hline Geossistêmico & $\begin{array}{l}\text { Baixo curso do Rio Paraíba; morfologia costeira, solo de florestas como } \\
\text { reservatórios de Carbono. }\end{array}$ \\
\hline Ecológico & $\begin{array}{l}\text { Manguezais enquanto berçário ecológico e substrato da vegetação; recifes } \\
\text { algálico- coralinos. }\end{array}$
\end{tabular}

Aforamentos, com seus fosseis, rochas, minerais e feições associadas, e geoformas que contribuem para entender a evolução da Bacia da Paraíba; estrato-tipo da Formação Gramame.

\begin{tabular}{cl} 
& estrato-tipo da Formação Gramame. \\
\hline História da Terra & $\begin{array}{l}\text { Várias teses se desenvolveram na área, pois a evolução da Bacia da Paraíba tem } \\
\text { relação aos últimos estágios de fragmentação do Gondwana. }\end{array}$ \\
\hline $\begin{array}{c}\text { Monitoramento } \\
\text { ambiental }\end{array}$ & Análise sedimentológica; paleossolos. \\
\hline $\begin{array}{c}\text { Educação e } \\
\text { treinamento }\end{array}$ & $\begin{array}{l}\text { Se potencializam nos sítios: morfologia costeira; feições de movimento de massa; } \\
\text { falésias, entre outras, que vem sendo utilizados na formação de estudantes, em } \\
\text { pesquisas de campo. }\end{array}$
\end{tabular}

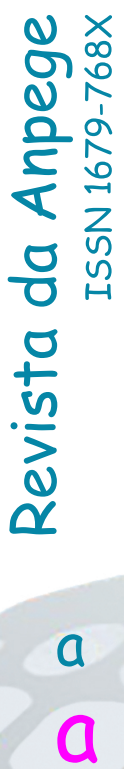


A $2^{\text {a }}$ etapa do projeto PRODETUR-NE teve início em 1999. Nesta fase, a política pública estaria voltada ao saneamento dos problemas verificados na $1^{\text {a }}$ etapa e a incorporação dos princípios do Desenvolvimento Sustentável (BANCO DO NORDESTE DO BRASIL, 2002). Entre estas obras, estava a edificação do Centro de Convenções de João Pessoa, cuja escolha recai para às margens da rodovia PB-008, a poucos metros da ponte do Rio Jacarapé. Assim, na prática, o discurso oficial não se compatibilizou com a prática. Boa parte destas ações foram efetivas ameaças à geodiversidade da área, conforme proposto por Gray (2004). Alguns dos elementos e feições descritas no texto podem ser visualizados na figura 3. Para melhor entendimento, leia a legenda.

Figura 3 - Exemplo de danos à geodiversidade e biodiversidade, causado pela extração mineral e expansão urbana. Área entre a bacia do Rio Cuiá, abaixo, o Rio Aratu, acima, com o Parque Estadual do Jacarapé delimitado em preto. Às margens da PB-008 foi construído o Centro de Convenções, que causou desmatamento de Mata Atlântica do Parque Estadual do Jacarapé. Nos arredores, dois bairros populosos, Cidade Verde e Costa do Sol, pressionam a reserva. O barramento do Rio Jacarapé é consequência da instalação da referida rodovia. O círculo vermelho indica a área em que foi extraída areia e barro, na fase inicial do projeto Costa do Sol, em 1989, e que acarretou em uma cicatriz de exposição dos sedimentos da Formação Barreiras. Norte para cima.

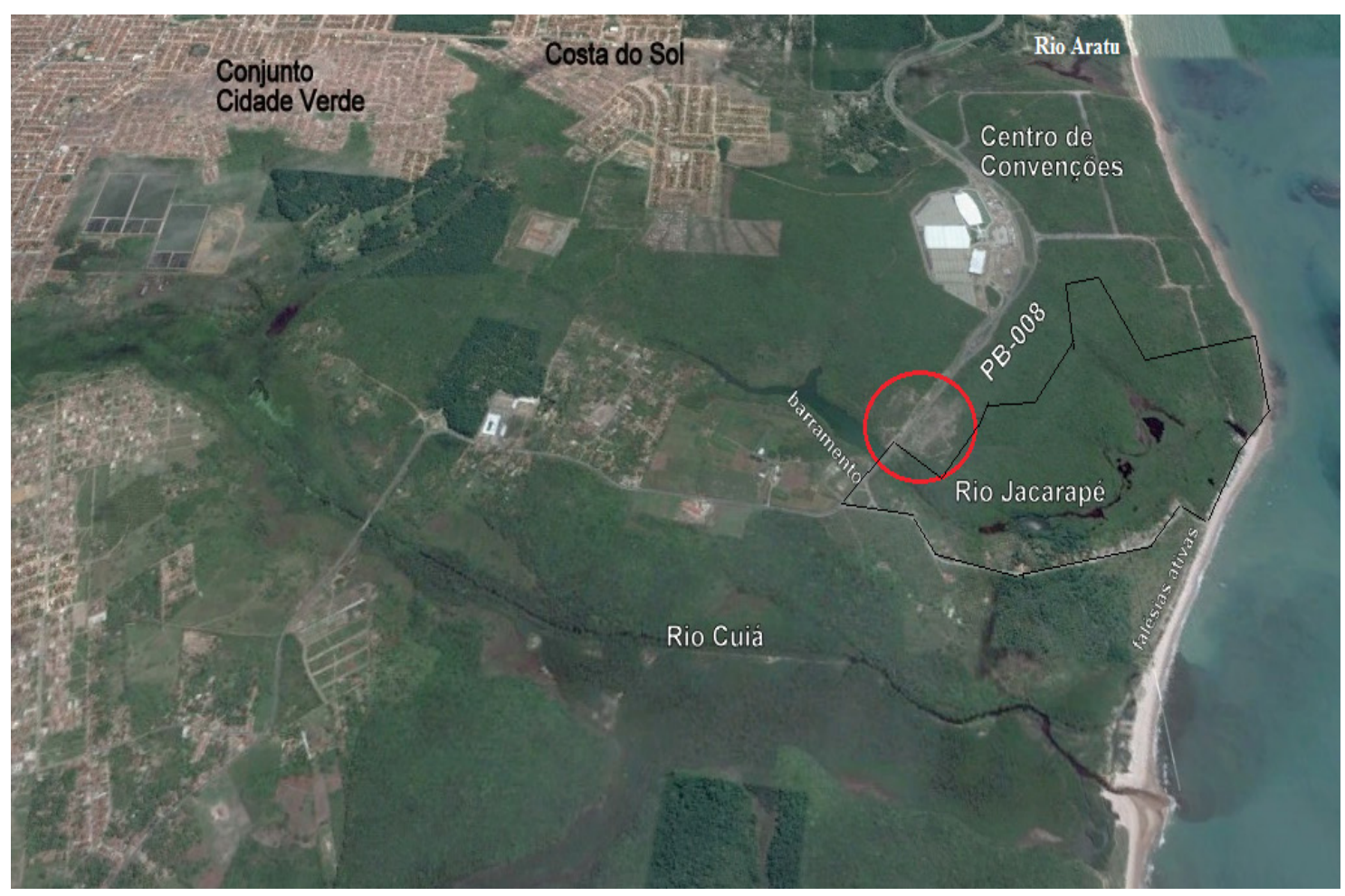

Fonte: Google Earth.

- Expansão urbana e obras- estruturas: o papel da indústria da construção civil, expandido a verticalização urbana que causam impactos sobre a geodiversidade ao serem construídos sobre afloramentos rochosos com estruturas peculiares ou 
fósseis, ou geram a remoção do solo e sua compactação. A infraestrutura urbana pode acelerar processo erosivos, com a construção de estradas, o desmatamento, a ocupação irregular de encostas ou áreas de mananciais, agravando as enchentes e os desabamentos de encostas. A minimização destes impactos devem fazer parte destes projetos.

O desenvolvimento pelo qual passou o Brasil, a partir dos anos 1950, acarretaram em uma série de obras de grande envergadura que trouxeram graves consequências à geodiversidade. Entre elas, citamos a construção de extensas rodovias e algumas poucas ferrovias e hidrovias; a industrialização intensa e desmedida, sem nenhuma medida de proteção, cujos dejetos sólidos poluem rios e mares, gases poluem a atmosfera; edificação sobre manguezais, a exemplo do que ocorre nos arredores do Shopping Center Manaíra, em João Pessoa, entre outras obras.

- Restauração de aterros e pedreiras: pedreiras e aterros abandonados acabam se tornando depósito de um série de detritos sólidos, como lixo, orgânico e inorgânico, que, ao se decompor, pode contaminar o lençol freático, prejudicando a qualidade das águas subterrâneas, além de liberar metano para a atmosfera, contribuindo para o efeito estufa. Ademais, o lixo tóxico, hospitalar e da agricultura, pode contaminar o solo, inviabilizando-o para a agricultura por décadas ou séculos. Estes resíduos, somados à carga de sedimentos que se acumulam por processo naturais, como a erosão e intemperismo, podem esconder os afloramentos rochosos do local. Uma antiga pedreira de calcário abandonada, no distrito de Caxeté, município do Conde, por exemplo, tornou-se depósito de lixo e já se encontra em processo de aterramento, mostra este tipo de ameaça à geodiversidade na área de estudo.

- Manutenção dos rios, hidrologia e obras de engenharia: a interferência humana sobre os recursos hídricos é uma prática comum, através do desmatamento de matas ciliares, para a pratica agrícola, e a canalização, barramento, desvio de rios, poluição, entre outras ações. Este desmatamento ocasiona o assoreamento dos rios, resultando em desequilíbrios no ecossistema fluvial, ao reduzir a profundidade e largura dos rios, aumentando o despejo de sedimentos no oceano, entre outras consequências da alteração no fluxo sedimentar. Um dos principais rios urbanos da área deste estudo é o Rio Jaguaribe. Este rio apresenta-se totalmente descaracterizado de suas características originais, bastante assoreado, canalizado e, inclusive, foi desviado de seu trajeto, mudando a localização de sua foz. 
- Silvicultura, crescimento da vegetação e desmatamento: a presença de plantio de árvores em uma grande área, ou o crescimento de maneira espontânea, pode recobrir afloramentos rochosos ou perfis de solo e, até mesmo, atrapalhar a visualização de geoformas, assim como a serapilheira associada a elas ou o crescimento e liquens pode esconder minerais em um afloramento rochoso.

Por outro lado, o desmatamento gera consequências a curto, médio e longo prazo. Além dos problemas ambientais clássicos, como a extinção de espécies vegetais,o aumento das temperaturas globais pela menor quantidade de carbono retido pelas plantas, exposição do solo à erosão e assoreamento de rios, conforme referido anteriormente, esta erosão pode evoluir para um processo de ravinamento e criação de voçorocas que, uma vez formadas, torna-se de difícil contenção. Estas voçorocas, ao expor rochas subjacentes, tem o ponto positivo de proporcionar vê-las e estudá-las mas, por outro lado, as expõe ao intemperismo. Mesmo que João Pessoa seja bem provida de áreas florestais, a exemplo da Mata do Buraquinho, com 530 ha, estudos recentes mostram que o avanço da agricultura está causando intenso desmatamento nos arredores do Rio Paraíba (STEVENS, 2014), assim como áreas do litoral sul, por exemplo, estão susceptíveis a esta ameaça devido à pressão imobiliária.

- Pressão turística/ recreacional: a atividade turística causa sérios danos à geodiversidade quando não for desenvolvida com sustentabilidade. Em parques naturais sob intensa visitação em épocas de pico, aumenta o despejo de lixo, o barulho, a poluição do ar e deterioração da vegetação em trilhas clandestinos. Em visitas a cavernas, é praxe os guias serem enfáticos ao pedirem para os turistas evitar tocar nas paredes, para não causar dano à rocha. Em áreas costeiras, como as deste projeto, a expansão de facilidades turísticas tem causados significativos danos ao balanço geomorfológico original, assim como a dinâmica natural da linha de costa. Entre estas facilidades, destaca-se a construção de resorts no alto das falésias paraibanas, com vista panorâmica para o oceano, causando uma pressão às falésias, acentuando o risco de desabamento. Em Cabedelo, município conurbado à João pessoa, um dos destinos preferenciais para visitação turística é o banco de areia da praia de Camboinha conhecido como Areia Vermelha. No verão, após um dia de idas e vindas de turistas, o cenário é desolador: muito lixo sólido, fragmentos de carvão pela praia, resultado de 'churrasquinhos', pedaços dos recifes deteriorados, entre alguns impactos ocorridos, mesmo sendo um Parque Estadual Marinho e, portanto, salvaguardado de tais crimes ambientais. Mesmos problemas ocorrem em outros pontos de visitação, a exemplo do Recife de Picãozinho, Praia do Jacaré, 
falésias do litoral sul, que estão sofrendo com a pressão imobiliária e a construção de resorts e hotéis em seu topo, entre outros locais.

Um outro agravante são as trilhas turísticas, ao longo da linha de costa, que potencializam o desabamento de encostas em áreas íngremes, como nas falésias, por exemplo.

- Remoção de espécimes geológicos para fins não-científicos: as rochas, minerais, gemas e fósseis, quanto mais coloridos e exóticos parecerem, tem atraído a atenção de colecionadores do mundo todo. Assim, é muito comum visitantes de determinados locais, sejam eles colecionadores ou não, que tem no meio abiótico seu maior atrativo, acabarem por retirar amostras de afloramentos, o que causa um dano irreversível, pois são materiais não-renováveis. Acrescenta-se os danos causados aos afloramentos na tentativa de extração de espécimes específicas, como fósseis ou geodos de ametista, em minas, cujas aberturas se dão através da sistemática utilização de explosivos potentes. Mesmo que a extração para fins científicos tenha efeito semelhante, sua ação se justifica para o conhecimento científico (BRILHA, 2005, p. 48).

Vários afloramentos na área possuem valor pedagógico, como visto anteriormente. Assim, esta prática de coleta de amostras pode danificar o local, levando a um prejuízo inestimável, necessitando o monitoramento dos responsáveis pelas visitas.

- Agricultura: o manejo adequado do solo, através da reposição de nutrientes no solo e da prática da rotação de culturas, tem propiciado uma maior conservação das características naturais do solo. Entretanto, algumas técnicas consideradas úteis para a agricultura, como o terraceamento, pois minimiza os efeitos da erosão, por outro lado modificam o declive natural das geoformas. A compactação do solo por tratores também pode danificar o solo, pois a água que infiltraria, acaba por escoar, intensificando o processo erosivo. Ademais, a prática de arar o solo pode danificar feições paleoambientais, como paleodunas, por exemplo. Considerando-se que a área apresenta uma intensa atividade agrícola extensiva, boa parte sobre paleodunas, principalmente minifúndios de subsistência, este tipo de ameaça é recorrente na área.

Outro tipo de problema concernente à agricultura extensiva é a prática das queimadas. Os incêndios podem ter origem natural (um raio ou atividade vulcânica) mas, na maioria das vezes, são induzidos pelo homem, seja por motivos criminosos, involuntários ou, no caso em questão, para a agricultura. Neste caso, nos países subdesenvolvidos, uma prática recorrente de limpeza do solo são as queimadas. A longo prazo, elas prejudicam 
o solo, tornando impróprio para a agricultura. No litoral nordestino, em especial nas áreas canavieiras e nos minifúndios policultores que visam a subsistência, esta prática é corriqueira, trazendo sérios prejuízos ao solo.

- Mudança no nível do mar e climática: afora a polêmica discussão acerca do aquecimento global, é sabido que, principalmente nas áreas de altas latitudes, algumas mudanças estão ocorrendo que são sérias ameaças à geodiversidade. Entre elas, cita-se a fusão do permafrost, com afundamento da superfície e erosão das áreas fundidas, com consequência para construções, vegetação e estradas sobre elas. O derretimento de glaciares em áreas montanhosas expõe a superfície rochosa sob eles, e seu consequente intemperismo. Entretanto, são nas zonas costeiras que os impactos se intensificam.

A área deste estudo possui cerca de $60 \mathrm{Km}$ de litoral, constituído por 25 praias. O balanço sedimentar intercala áreas com deposição e erosão marinha, o que é considerado um processo natural e necessário para os ecossistemas costeiros. Entretanto, a construção de obras que adentram a linha de costa ou de contenção do avanço do mar, causam modificações na dinâmica oceanográfica e no balanço sedimentar. Na Ponta do Bessa, por exemplo, o avanço do nível do mar ocasionou a destruição parcial do Iate Clube e de algumas residências vizinhas, e obras para minimizar a erosão marinha naquela porção foram construídas, em vão. Este fenômeno natural acaba por ser agravado pela intervenção antrópica, através da especulação imobiliária e obras mal planejadas. Em maio de 2015, parte da falésia de Cabo Branco desabou, causando grande apreensão pela proximidade ao farol de Cabo Branco, geossímbolo da capital paraibana.

Outras consequências do avanço do nível do mar inclui a submersão de ilhas rasas, como aconteceu em Tuvalu, na Polinésia Francesa, em 2002, perda de pântanos e manguezais e intrusão de águas salinas em reservatórios de água doce (Gray, 2004, p. 166).

- Atividade militar: as rotinas de operações militares e treinamentos, com o uso de maquinaria pesada, abertura de trincheiras, escavação de túneis, lançamento de granadas podem degradar áreas sensíveis. O 15º Batalhão de Infantaria Motorizada de João Pessoa, por exemplo, utiliza a Praia do Sol como área para operações de busca e resgate e simulações de combate. Nestes eventos, os pelotões arremessam granadas e morteiros em dunas, causando danos e abrindo crateras, cujos sedimentos são carreados pelo vento posteriormente, além das escaladas em falésias, que são sensíveis ao contato antrópico. 
- Iliteracia cultural: consequência da ignorância e do desconhecimento por falta de informação acerca da geodiversidade e do geopatrimônio. É resultante da exclusão de pesquisadores das Ciências da Terra em discussões que pautem a conservação da natureza, o que acaba centralizando o foco das atenções para o meio biótico. Para reverter este quadro, é necessário que as entidades acadêmicas que tratem do assunto se mobilizem, se façam presentes em fóruns públicos e administrativos e demarquem o terreno de atuação, mostrando que a geodiversidade é tão importante, se não mais, que a biodiversidade. Como exemplo, esta negligência se mostra em alguns cursos de Geologia no país que não possuem na grade curricular disciplinas que envolvam a temática 'Geopatrimônio', 'Geodiversidade,' 'Geoconservação' ou 'Geoturismo'. Não se pode negar que esta atuação se intensificou nos anos 1990, mas ainda pode haver um fortalecimento maior. No caso da Paraíba, agrava-se o fato dos institutos de ensino superior não possuírem o curso superior de Geologia, e os de Geografia não contemplarem as referidas disciplinas.

Todos estes exemplos provam a errônea e disseminada mentalidade de que os recursos naturais, em especiais os abióticos, são estáticos, estáveis e pouco susceptíveis à alterações. Considerando que boa parte destes elementos servem como georecursos às populações contemporâneas, reconhecer estas ameaças e mitigar seus danos deve fazer parte do planejamento estatal equilibrado e consciente das limitações da geodiversidade.

\section{CONCLUSÕES}

Fazem parte da geodiversidade os materiais geológicos (rochas e seus elementostexturas, estruturas, minerais e fósseis, assim como os processos que o geraram ou que os deformam, como a tectônica, gerando dobras, falhas e brechas), analisados em uma escala, normalmente, de afloramento; geomorfológicos (depósitos, geoformas e os processos que deram origem), analisado em todas as escalas; pedológicos e hidrológicos (superficiais ou subsuperficiais- doce ou salgada), tendo a ação antrópica um papel fundamental de interferência nas características destes elementos.

O município de João Pessoa e arredores, incluindo o litoral sul, tem passado por inúmeras transformações nas últimas décadas, em decorrência de um fluxo sem igual de pessoas do interior e de outros Estados e regiões que escolheram a região para morarem, em busca de qualidade de vida e melhoria socioeconômica, resultando em um aumento brusco na população total e, consequentemente, na pressão sobre o meio natural e sua geodiversidade, típico de zonas costeiras. 
A paisagem natural ímpar resultou em bens de inegável importância histórica, científica, pedagógica, turística, entre outros valores, o que lhe imprime um caráter patrimonial. Assim, dentro de uma perspectiva patrimonial, os elementos abióticos da paisagem merecem ser preservados por possuírem valor científico, estético, educacional, ou qualquer outro que seja, responsável por sua motivação na preservação do bem. Torna-se pertinente, portanto, num primeiro momento, o reconhecimento e divulgação dos valores da geodiversidade, voltada à disseminação das Geociências a um público mais amplo, com vistas a sua patrimonialização.

Sua natureza privilegiada resulta na apropriação deste ambiente costeiro, em práticas de lazer, turismo, educacionais, desportivos, entre outros, que geram forte pressão, ocasionando efetivas ameaças à geodiversidade. O reconhecimento da vulnerabilidade deste geopatrimônio, através de uma série de ameaças, torna possível ampliar as discussões para estratégias de geoconservação que visem dilatar sua tão importante existência para usufruto das gerações futuras.

\section{AGRADECIMENTOS}

Esta pesquisa foi financiada pela CAPES/ CSF (projeto no 11988/13-4), a qual o autor principal é bolsista de Doutorado Pleno em Geografia Física na Universidade de Coimbra, Portugal.

\section{REFERÊNCIAS}

1. BANCO DO NORDESTE DO BRASL. PRODETUR / NE II: Apresentação. Fortaleza: Banco do Nordeste: 2002. Disponível em: <http://www.bnb.gov.br/content/aplicacao/PRODETUR/ prodetur_ne2/gerados/apresentacao.asp?idTR=prodetur >.Acesso em 17 fevereiro 2014.

2. BRILHA J.Património Geológico e Geoconservação. A Conservação da Natureza na sua vertente Geológica. Palimage Editores, Viseu, 2005.

3. COVELLO, C. A paisagem de Itapema: estudo da geodiversidade para a educação ambiental e o geoturismo. Dissertação (Mestrado em Geografia), Universidade Federal de Santa Catarina, Florianópolis, 2011.

4. CRUZ, R. C.Política de turismo e território. São Paulo: Contexto, 2000.

5. FARIAS, E.; BARCELLOS, L. A Religiosidade dos Indígenas Tabajara na Paraíba. Seminário Nacional de Formação de Professores para o Ensino Religioso, 13, Belém. Anais..., Belém: FONAPER, 2014.

6. GIL, A. C. Como elaborar projetos de pesquisa. São Paulo: Atlas, 1991. 
7. GRAY, M.Geodiversity: Valuing and Conserving Abiotic Nature. Chicheste: John Wiley and Sons, 2004.

8. GRAY, M.Geodiversity: the origin and evolution of a paradigm. In: BUREK, C. V.; PROSSER, C. D. (eds) The history of Geoconservation. The Geological Society, London, Special Publications, 300, p. 31- 36, 2008.

9. MANOSSO, F. C.Potencialidades da paisagem na região da Serra do Cadeado- PR: abordagem metodológica das relações entre a estrutura geoecológica, a geodiversidade e o geoturismo. Tese (Doutorado em Geografia), Universidade Estadual de Maringá, Maringá, 2012.

10. MANSUR, K. L.Diretrizes para Geoconservação do Patrimônio Geológico do Estado do Rio de Janeiro: o caso do Domínio Tectônico Cabo Frio. Tese (Doutorado em Geologia), Universidade Federal do Rio de Janeiro, Rio de Janeiro, 2010.

11. MANSUR, K. L.; SILVA, A. S. Society's response: Assessment of the Performance of the "Caminhos Geológicos" (“Geological Paths") Project, State of Rio de Janeiro, Brasil. Geoheritage n. 3, p. 27-39, 2011.

12. MEDEIROS, C.O Tambiá da minha infância. João Pessoa: União Editora, 1994.

13. MINAYO, M. C. S. (Org.) Pesquisa social: teoria, método e criatividade. 2. ed. Rio de Janeiro: Vozes, 2000.

14. MINISTERIO DO MEIO AMBIENTE. Avaliação e ações prioritárias para a conservação da biodiversidade das zonas costeira e marinha. Ministério do Meio Ambiente, 2000. Disponível em http://www.anp.gov.br/brasilrounds/round8/round8/guias_r8/perfuracao_r8/Bibliografia/ MMA2002.PDF. Acesso em 21 maio 2015.

15. MOURA, A. K.O mito do desenvolvimento sustentável do turismo: uma análise crítica das teorias de sustentabilidade, das políticas públicas e do discurso oficial do turismo a Paraíba. Dissertação (Mestrado em Desenvolvimento e Meio Ambiente), Universidade Federal da Paraíba, João Pessoa, 2008.

16. MOURA, A. K.; GARCIA, L. G. O Discurso do Turismo Sustentável no Contexto do Polo Turístico Cabo Branco, João Pessoa, PB. Encontro da Sociedade Brasileira de Economia Ecológica, 7, 2007, Fortaleza. Anais... Fortaleza: UFC, 2007.

17. NIETO, L. M.Geodiversidad: propuesta de uma definición integradora. Bol. Geol. Y Min., vol. 112, n. 2, p. 3- 12, 2001.

18. PANIZZA, M.; PIACENTE, S.Cultural geomorphology and geodiversity. In: E. REYNARD; CORATZA, P; REGOLINI-BISSIG, G. (Eds). Geomorphosites.Verlag Dr. Friedrich Pfeil, München, p. 35- 48, 2009.

19. PEDROSA, I. L.A gestão ambiental e o Polo Turístico Cabo Branco: Uma abordagem sobre desenvolvimento e meio ambiente. Dissertação (Mestrado em Desenvolvimento e Meio Ambiente), Universidade Federal da Paraíba, João Pessoa, 1999.

20. PEREIRA, L. S.; OLIVEIRA, B. G. L.; VIEIRA, K. G. Praça da Pedra: an example of a geohistoric monument degraded in João Pessoa, PB. International Conference on Geography and Geosciences, 2013, Paris. Anais...Paris: WASET, p. 300, 2013. 
21. PIEKARZ, G. F.; LICCARDO, A. Programa Sítios Geológicos e Paleontológicos do Paranásituação atual e tendências. Cong. Bras. Geol., 43, 2006, Aracaju. Anais... Aracaju: SBG, pg. 89, 2006.

22. PIERRI, G. C.Geodiversidade do substrato da plataforma continental leste potiguar e habitats associados: região de Pirangi- RN (NE do Brasil). Tese (Doutorado em Geologia), Universidade Federal do Rio Grande do Norte, Natal, 2015.

23. PRESS, F., SIEVER, R., GROTZINGER, J., JORDAN, T.Understanding Earth. W. H. Freeman and Company.4 ed., 2003.

24. RODRIGUEZ, W.Roteiro Sentimental de uma Cidade. Editora Brasiliense, 1962.

25. SANTA TERESA, Padre P. G.Istoría délie Guerre Del Regno Del Brasile accadute tra la Corona di Portogallo e la Republica di Olanda.Roma: Stamperia degl'Eredi Del Corbelletti, 1698, p. 78- 79; 116- 117.

26. SERRANO, E.; RUIZ- FLAÑO, P. Geodiversity. A theorical and applied concept. Geog. Helv., n. 62, p. 140- 147, 2007.

27. ___ Geomorphosites and geodiversity. In: E. REYNARD; CORATZA, P.; REGOLINIBISSIG, G. (Eds). Geomorphosites. Verlag Dr. Friedrich Pfeil, München, p. 49- 61, 2009.

28. SERVIÇO GEOLÓGICO DO BRASIL- CPRM. Mapa Geodiversidade do Brasil. Escala 1:2.500.000.Legenda expandida. Brasília: CPRM/ Serviço Geológico do Brasil, 2006, 68 p. Disponível em http://www.cprm.gov.br/publique/media/planeta_terra.pdf._Acesso em 21 maio 2015.

29. SERVIÇO GEOLÓGICO DO BRASIL- CPRM. Mapa Geodiversidade do Estado da Paraíba, escala, 1: 500.000. Brasília: CPRM/ Serviço Geológico do Brasil, 2013. Disponível em. Acesso em 21 maio 2015 .

30. SHARPLES, C.Geoconservation in forest mangement: principles and procedures. Tasforests, v. 7, p. 37- 50, 1995.

31. SHARPLES, C.Concepts and principles of Geoconservation. Tasmanian Parks \& Wildlife Service, Hobart, 2002.

32. STEVENS, P. Dinâmica da paisagem no geossistema do Estuário do Rio Paraíba- Extremo Oriental das Américas: estimativas de perdas de habitat e cenários de recuperação de biodiversidade. Dissertação (Mestrado em Geografia), Universidade Federal da Paraíba, João Pessoa, 2014.

Artigo recebido em 16 de dezembro de 2015.

Artigo aceito em 30 de março de 2016. 